\title{
Egg development, hatching rhythm and moult patterns in Paralomis spinosissima (Decapoda: Anomura: Paguroidea: Lithodidae) from South Georgia waters (Southern Ocean)
}

\author{
William D. K. Reid · Jamie Watts · Sarah Clarke • \\ Mark Belchier $\cdot$ Sven Thatje
}

Received: 20 December 2006 / Revised: 6 March 2007 / Accepted: 12 March 2007 / Published online: 25 April 2007

(C) Springer-Verlag 2007

\begin{abstract}
Larval release, hatching rhythms and moult patterns were examined in a captive population of the subantarctic lithodid, Paralomis spinosissima from the South Georgia and Shag Rocks region. Larvae hatched throughout the year with the majority of females starting to release larvae at the end of the austral summer and beginning of autumn. Larval release continued over a period of up to 9 weeks with high variability in the numbers that hatched each day. A similar seasonal pattern to hatching was evident in the moulting of females. Intermoult period for two adult females $(\mathrm{CL}=63$ and $85 \mathrm{~mm})$ ranged from 894 to 1,120 days while an intermoult period for males was estimated to be in excess of 832 days. The results are consistent with other species of Paralomis and are discussed in relation to physiological and environmental adaptations to the coldwater conditions south of the Antarctic Convergence.
\end{abstract}

Keywords Antarctica - Crustacea - Cold adaptation . Stone crab $\cdot$ King crab

\section{Introduction}

The Antarctic reptant decapod fauna consists of about a dozen known species of crabs belonging to the family

W. D. K. Reid · J. Watts · S. Clarke · M. Belchier Biological Sciences Division, British Antarctic Survey, Natural Environment Research Council, High Cross, Madingley Road, CB3 OET Cambridge, UK

\section{S. Thatje $(\square)$}

National Oceanography Centre, Southampton,

School of Ocean and Earth Science, University of Southampton,

European Way, SO14 3ZH Southampton, UK

e-mail: svth@noc.soton.ac.uk
Lithodidae (Thatje and Arntz 2004). Lithodid crabs commonly known as "king crabs" or "stone crabs" are typical representatives of high latitudes (Zaklan 2002) and are of great importance to fisheries in both hemispheres (Dawson 1989). They are slow maturing crabs (Lovrich 1997) and have a high diversity in Subantarctic waters (Zaklan 2002). Five species of lithodid crabs are caught as bycatch in the commercial fisheries operating around the sub-Antarctic island of South Georgia (Morley et al. 2006). Paralomis spinosissima and Paralomis formosa are regularly caught as bycatch in the longline fishery for Patagonian toothfish (Dissostichus eleginoides) and attempts have been made to target them commercially (Purves et al. 2003).

Since the early 1990s there has been interest in exploiting stone crabs in South Georgia waters, and in 1993 a precautionary catch limit was set by the Commission for the Conservation of Antarctic Marine Living Resources (CCAMLR) for this species (Collins et al. 2002). An exploratory pot fishery was undertaken in 1992 mainly targeting Paralomis spinosissima (Otto and MacIntosh 1996). The results of the exploratory fishery suggested that crab resources in South Georgia waters (CCAMLR subarea 48.3) are large enough to provide a viable fishery (Otto and MacIntosh 1996). Although no commercial fishery has operated since 2001/2002 the crab fishery around South Georgia remains an exploratory fishery regulated by CCAMLR and subject to an exploratory fishing plan (Agnew 2004), with a catch limit of 1,600 tonnes per annum and minimum size limits of $102 \mathrm{~mm}$ carapace length (CL) for Paralomis formosa, and $90 \mathrm{~mm}$ CL for $P$. spinosissima.

This study presents the first data on the moult, egg extrusion and larval hatching patterns in adult Paralomis spinosissima collected from waters around South Georgia, and maintained under controlled laboratory conditions. 
Such knowledge is an important contribution to assessing the resilience potential of cold-water crab stocks to exploitation and to implement adequate management tools.

\section{Materials and methods}

Adult specimens of Paralomis spinosissima were obtained as by-catch by scientific observers working in the commercial longline fishery for Patagonian toothfish (Dissostichus eleginoides) around South Georgia from June 2001 to July 2006. Further specimens were collected during the annual bottom trawl research survey on the FPV "Dorada" undertaken each January around South Georgia and the Shag Rocks. On capture carapace length (CL), carapace width, chela height, chela length, and specimen weight were recorded. Crabs were held in tanks in the controlled temperature facility at the King Edward Point applied fisheries research station (British Antarctic Survey). They were kept in re-circulating seawater at $1.8-3.0^{\circ} \mathrm{C}$ and a salinity of 33-35 ppt, with an artificial light/dark cycle run by an outside photocell to match seasonal day length. Crabs were fed fish and squid weekly, and monitored daily. Crabs were kept in tanks of 4-10 individuals of mixed genders. Timing and duration of moulting was recorded as it occurred. Due to the small numbers of crabs surviving a full intermoult period, minimum premoult periods are given as an indication of length of time between moults; i.e. period from time of capture to the first moult, and are denoted $*$ in the results. Every month, crabs were examined in detail and egg development of the females was noted. When present, egg development was recorded as non-ovigerous, uneyed, eyed, dead eggs or empty egg cases. A simple index of abdominal cavity fullness was recorded; no eggs to trace, $<1 / 4$ full, $1 / 4$ to $1 / 2$ full, $1 / 2$ to $3 / 4$ and $3 / 4$ to full. Further anecdotal information on condition of the carapace and egg mass was documented. When a crab started releasing eggs it was isolated from the main tanks in a separate flow-through system, and the number of live larvae released was recorded daily.

\section{Results}

\section{Rearing history of Paralomis spinosissima}

A total of 51 female (range CL 47-90 mm), 41 male (range CL 40-100 mm) and three juvenile (range CL 20-36 mm) $P$. spinosissima were maintained in captivity over the period 2001-2006. Mean survival time in the facility was $485.9 \pm 328.5$ days for females, $379 \pm 330.7$ days for males, and $167.0 \pm 48.1$ days for juveniles.
Moult cycle

Moulting occurred throughout the year in females and males (Fig. 1). No males survived a full intermoult period of two consecutive moults. In males, time from capture to death without a moult ranged from 14 to 1,307 days ( $n=34, \mathrm{CL}=40-100 \mathrm{~mm}$ ) while time from capture to moult ranged from 306 to 639 days $(n=7, \quad \mathrm{CL}=40$ $92 \mathrm{~mm}$ ). Time from capture to death without a moult in females ranged from 18 to 632 days $(n=23, \mathrm{CL}=62$ $89 \mathrm{~mm}$ ) while time from capture to moult ranged from 126 to 1,001 days $(n=28, \mathrm{CL}=47-90 \mathrm{~mm}$ ). Two female crabs $(\mathrm{CL}=67$ and $85 \mathrm{~mm}$ ) survived a full intermoult period to moult twice. Intermoult period for these two crabs were 894 and 1,120 days, respectively. Neither of these females successfully hatched larvae whilst in the holding facility. High mortality was associated with moulting. Three of the seven males and 13 of the 28 female that moulted died during the moult or within 2 weeks afterwards.

\section{Egg development and larval release}

Egg development, hatch period and post hatch period are shown in Fig. 2. Thirteen out of 14 crabs that hatched larvae were captured with uneyed embryos therefore it was not possible to ascertain total time taken for the embryos to become eyed. Mean length of time taken for larvae to hatch after eyespots developed was 238.7 days S.D. 41.1 (range 141-290 days).

The majority of hatch events occurred through mid to late summer except crab 13 and 14, which hatched larvae in winter. Larval release was continuous but numbers released per day fluctuated widely, between 0 and 307 larvae (Fig. 3). No relationship was observed between size of indi-

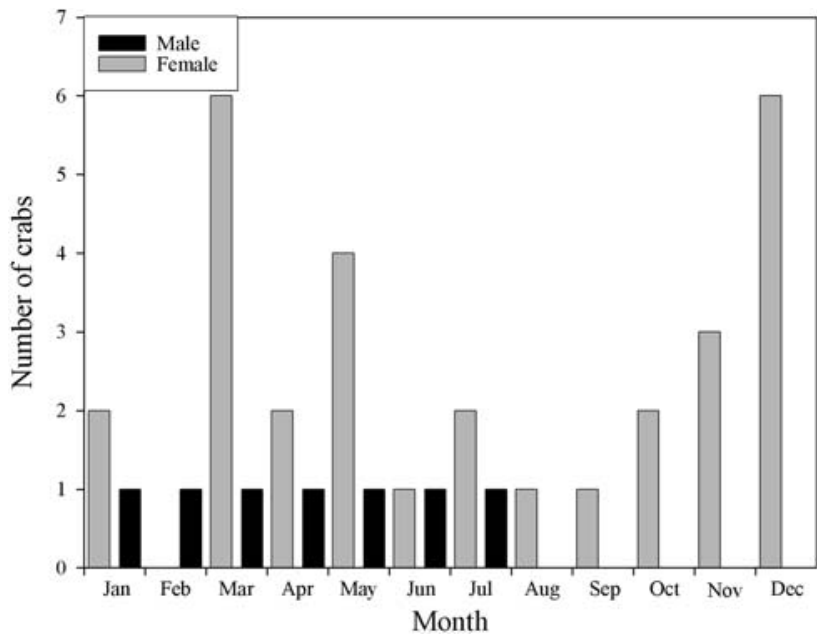

Fig. 1 Number of Paralomis spinosissima moulting per month in the temperature controlled facility at King Edward Point, South Georgia, from specimens collected between 2001 and 2006 around South Georgia 
Fig. 2 Paralomis spinosissima egg cycle starting of individuals caught around South Georgia and the Shag Rocks in January, between 2001 and 2006, with the carapace length $(\mathrm{mm})$ at the end of the bars

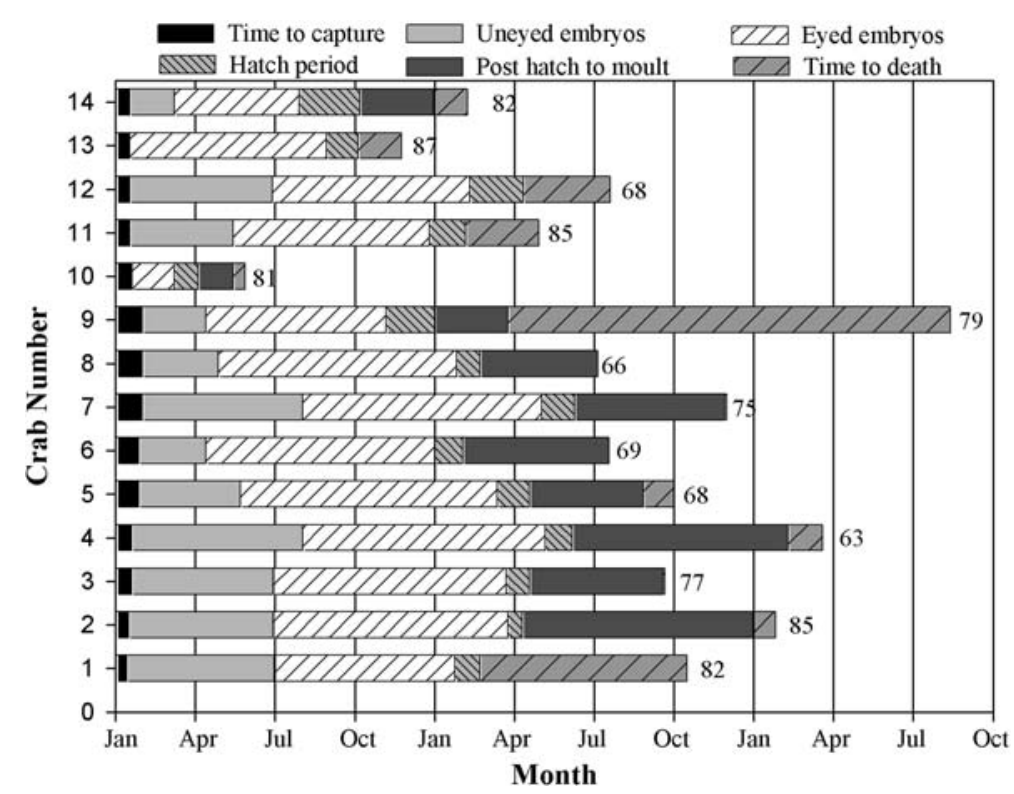

vidual and the number of larvae released (Table 1). According to the fecundity estimates calculated after Morley et al. (2006) in most females $1 / 4$ to $1 / 2$ of the clutch size remained with the female following hatching (Table 1). Crabs 6 and 14 were the only crabs to hatch nearly a full clutch of eggs (Table 1). In all other crabs, eggs turned brown and were released by the females after the hatch period.

\section{Discussion}

Egg development

Large eggs as seen in P. spinosissima (Morley et al. 2006) have the potential to store high-energy reserves facilitating endotrophic larval development (Anger et al. 2003, 2004). The lack of feeding appendages and observed food independent development in the larvae of $P$. spinosissima suggests lecithotrophic development (Watts et al. 2006), which coincides with patterns so far found in sub-Antarctic lithodids (Thatje et al. 2005). Similarity in the development mode of the larvae suggests that brood time in Paralomis species could be similar. P. granulosa broods eggs for 1822 months at much higher temperatures $\left(6-12^{\circ} \mathrm{C}\right)$ than found at South Georgia (Lovrich and Vinuesa 1999) and brood time in $P$. spinosissima is clearly greater than 12 months. Estimating an accurate length of brood time is difficult. It was not possible to determine duration of the uneyed stage from field-collected specimens as eggs were already present in the incubation chamber of females.

In $P$. granulosa the eyed period in embryos contributes $45-55 \%$ of the whole embryogenesis (Lovrich and Vinuesa 1993). Applying this relationship to P. spinosissima with a tentative estimation of 9-12 months uneyed and 511 months for eyed stage, suggests that the whole embryogenesis in this species may last between 432 and 528 days (=14-18 months). Although this is only a tentative estimation, it suggests that low water temperatures at South Georgia do prolong embryogenesis in $P$. spinosissima.

Hatching and larval release

The hatching mode in $P$. spinosissima is consistent with other species of southern hemisphere lithodids as low numbers of larvae released daily over a long continuous period. This has been observed in $P$. granulosa and $L$. santolla (Thatje et al. 2003) as well as in Paralithodes platypus from the northern hemisphere (Stevens 2006). P. spinosissima larvae hatched for up to 9 weeks before the cessation of release. This is likely to be an underestimation of the hatching period in the wild, as eleven out of thirteen females had half to three-quarters of the their clutch present at the end of their releasing event, assuming that the majority of the clutch is released. In the wild, hatching could be as long as 12 weeks when release numbers are compared with an estimation of fecundity, calculated using equations by Morley et al. (2006).

Females showed no signs of abdominal flapping during larval release, as found in temperate crab species (Baeza and Fernandez 2002). From a physiological perspective, it had been suggested that brooding activities should be reduced at lower temperatures as a result of reptant decapods being poor $\mathrm{Mg}^{2+}$ regulators and the possible narcotising effect at low temperatures and high $\mathrm{Mg}^{2+}$ in the haemolymph (Frederich et al. 2001). Thatje (2004) has hypothesised that embryonic development may not only be completely genetically constrained but could also depend 


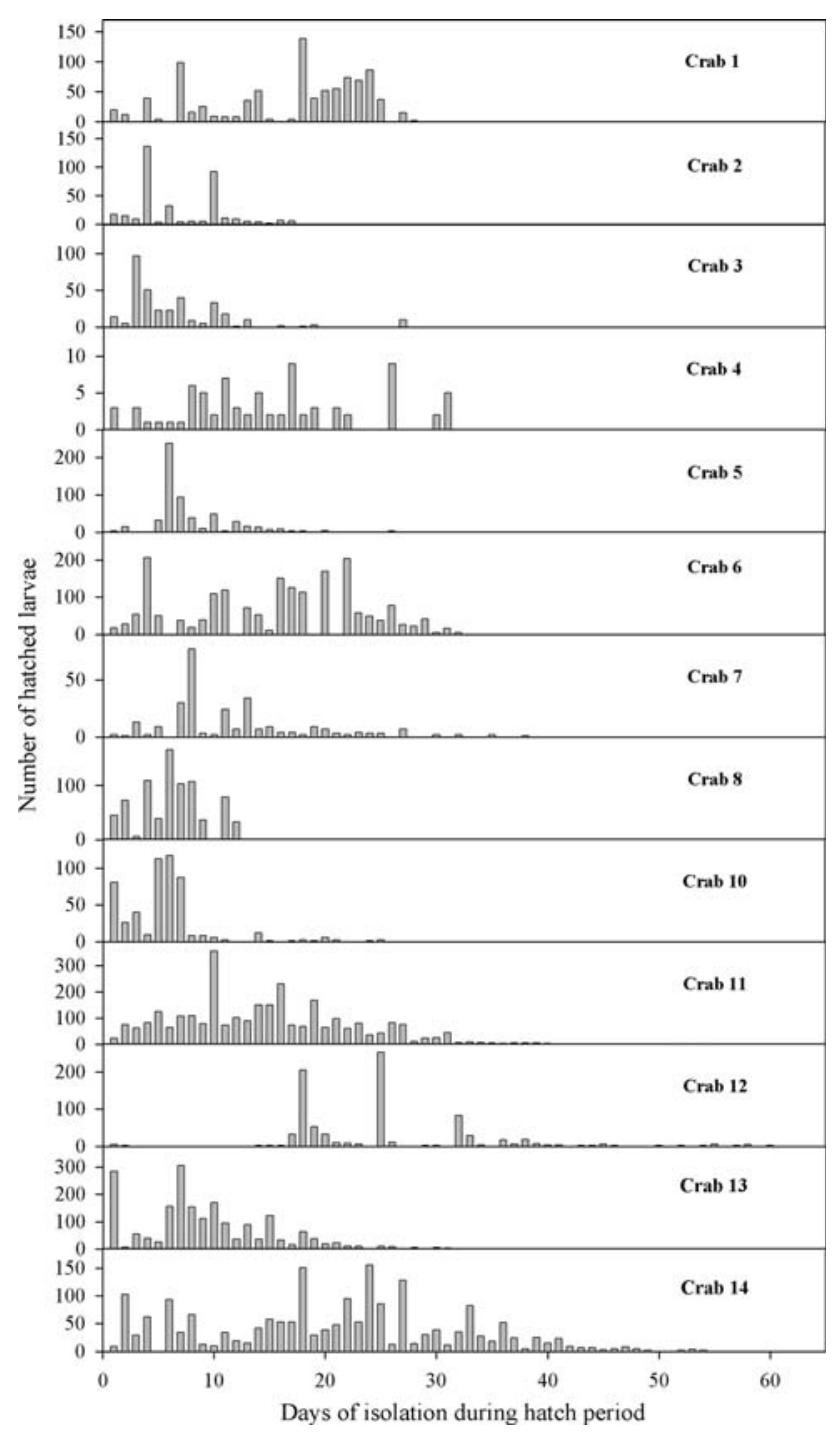

Fig. 3 Daily number of larvae hatched by Paralomis spinosissima from specimens caught around South Georgia and the Shag Rocks between 2001 and 2006

on a combination of temperature and oxygen concentration. Oxygen demand by developing larvae increases near to hatching (Thatje 2004). Low abdominal flapping and a decrease in oxygen concentration into the brood (Baeza and Fernandez 2002) may result in a lag in development close to the centre of the clutch increasing the duration of the releasing event. Aborted hatching rhythms in our experiments could indeed be an indication of physiological limits to brooding in the cold, which needs further investigation.

$P$. spinosissima has a lower fecundity than both P. granulosa and L. santolla (Lovrich and Vinuesa 1999; Morley et al. 2006) but larvae are released over a similar time frame and longer. Lecithotrophic development in lithodid species has been described as an adaptation to cold environments with short or variable seasonal primary productivity (Thatje 2004). This overcomes the need for food during lar- val development to crab I stage and buffers against the possible mismatch of food supply with hatching time. Shallowwater lithodids do show signs of seasonality in hatching. $P$. granulosa and $L$. santolla larvae hatch in winter and early spring between June and October (Hoggarth 1993; Lovrich and Vinuesa 1999). This coincides with development to crab stage I in spring and early summer in time for increased primary productivity and food availability. Larval release in P. spinosissima is year round. Start of hatching is highly skewed towards summer and decreases into autumn. It is not clear whether this is a result of a low sample size $(n=14)$ or if it is true for the whole population, which shows a much wider bathymetric distribution than species from Subantarctic Tierra del Fuego (Thatje et al. 2005). In July 1992, Otto and MacIntosh (1996) found a considerable variability in the development stage of wild $P$. spinosissima embryos during the experimental fishery around South Georgia and the Shag Rocks. Embryos were a mixture of uneyed to fully formed zoea, which suggested a great deal of variation in hatching time.

Intermoult periods

The intermoult periods of immature and mature male and female $P$. spinosissima (Table 1) were difficult to measure. The information collected on juvenile crabs is low and more data is needed. First year growth of a single crab between crab stage I and II was successfully achieved at $5^{\circ} \mathrm{C}$ in conjunction with morphological and biochemical larval studies (Watts et al. 2006) and first year growth in lithodids has been shown to be strongly scaling with temperature (Calcagno et al. 2005). The time between crab I and crab II in $P$. spinosissima was approximately 180 days (BAS, unpublished data), which is longer than in other species of lithodids (Calcagno et al. 2005). The time between intermoults is affected by temperature with increased intermoult duration with a decrease in temperature (Anger et al. 2003, 2004). Bottom temperatures around South Georgia are lower than $5^{\circ} \mathrm{C}$. Collins et al. (2002) found temperatures around South Georgia to vary between 1.4 and $2.2^{\circ} \mathrm{C}$. Lower temperatures in the wild would be expected to cause an increase in the intermoult duration of stone crabs in their first year (Calcagno et al. 2005). In $P$. granulosa the intermoult period doubles in time between 3 and $6^{\circ} \mathrm{C}$. If this holds true for $P$. spinosissima then the intermoult period in the wild could be as long one year in the first year of life.

Moulting in sexually mature lithodids is believed to tie in with its reproductive cycle. In the majority of species this process is seasonal (Lovrich and Vinuesa 1999). Mating occurs between a newly moulted male with a hard shell and a female with a soft shell. Eggs must be fertilised immediately as lithodids have no way of storing sperm (Zaklan 
Table 1 Carapace length ( $\mathrm{mm})$, total number of larvae released, total days in isolation, average daily hatch rates and theoretical fecundity as calculate based on CL using equations by Morley et al. (2006) for Paralomis spinosissima caught around South Georgia and the Shag Rocks. $n / a$ no data

\begin{tabular}{lllllll}
\hline Crab & $\begin{array}{l}\text { CL } \\
(\mathrm{mm})\end{array}$ & $\begin{array}{l}\text { Number } \\
\text { hatched }\end{array}$ & $\begin{array}{l}\text { Theoretical } \\
\text { fecundity }\end{array}$ & Hatch period & $\begin{array}{l}\text { Clutch size } \\
\text { before hatch }\end{array}$ & $\begin{array}{l}\text { Clutch size } \\
\text { after hatch }\end{array}$ \\
\hline 1 & 78 & 903 & 4,748 & 18.01 .05 to 15.02 .05 & $3 / 4$ to full & $1 / 2$ to $3 / 4$ \\
2 & 83 & 362 & 5,797 & 19.03 .05 to 04.04 .05 & $3 / 4$ to full & $3 / 4$ to full \\
3 & 76 & 345 & 4,328 & 17.03 .05 to 12.04 .05 & $3 / 4$ to full & $1 / 2$ to $3 / 4$ \\
4 & 63 & 79 & 1,600 & 30.04 .05 to 30.05 .05 & $3 / 4$ to full & $1 / 2$ to $3 / 4$ \\
5 & 68 & 573 & 2,650 & 07.03 .05 to 12.04 .05 & $3 / 4$ to full & $1 / 4$ to $1 / 2$ \\
6 & 69 & 1,912 & 2,859 & 26.12 .04 to 27.01 .05 & $3 / 4$ to full & $<1 / 4$ \\
7 & 75 & 275 & 4,118 & 26.04 .05 to 02.06 .05 & $3 / 4$ to full & $3 / 4$ to full \\
8 & 65 & 796 & 2,020 & 20.01 .05 to 15.02 .05 & $3 / 4$ to full & $1 / 4$ to $1 / 2$ \\
9 & 79 & n/a & n/a & 01.11 .04 to 15.12 .04 & $3 / 4$ to full & $1 / 2$ to $3 / 4$ \\
10 & 81 & 523 & 5,378 & 07.03 .05 to 03.04 .05 & $1 / 2$ to $3 / 4$ & $1 / 4$ to $1 / 2$ \\
11 & 85 & 2,869 & 6,217 & 20.12 .05 to 30.01 .05 & $3 / 4$ to full & $1 / 4$ to $1 / 2$ \\
12 & 68 & 843 & 2,650 & 04.02 .05 to 05.04 .06 & $3 / 4$ to full & $1 / 2$ to $3 / 4$ \\
13 & 85 & 1,941 & 6,217 & 07.05 .06 to 12.06 .06 & $3 / 4$ to full & $1 / 2$ to $3 / 4$ \\
14 & 82 & 1,940 & 5,587 & 11.08 .05 to 03.11 .05 & $3 / 4$ to full & $<1 / 4$ \\
\hline
\end{tabular}

2002). Moulting in female and male $P$. spinosissima was observed all year round but female moults were highly skewed towards the summer months. With the low sample size of males it is not possible to say whether they are moulting slightly earlier than females or whether the population as a whole is aseasonal. In other species of deepwater lithodids, Lithodes aequispina and Lithodes couesi, it has been suggested that life history patterns are less tied to surface productivity, temperature and food availability (Somerton 1981; Sloan 1985; Hoggarth 1993). The presence of moulting males and females in deep water lithodids throughout the year could be a consequence of movement away from a cycle linked to seasonal productivity or temperature.

Hoggarth (1993) suggested an intermoult period of 24 months for mature female and up to 36 months for mature male $P$. granulosa. These long intermoult periods were hypothesised to be a result of adaptations to harsh and energetically restricted conditions. A similar estimation of time between moults would be plausible for female $P$. spinosissima as the small number of females that survived for more than 2 years, within this study, did not undergo a moult. Further evidence for a long intermoult period was published by Otto and MacIntosh (1996) who observed biological fouling on the carapace of sexually mature crabs that indicated moult periods of 12 months and longer.

\section{Captive studies for life history investigations}

Keeping animals in an artificial environment can ultimately affect their growth and maturity resulting in misleading interpretations (Wenner et al. 1974). Stone crabs are relatively active decapods and are known to migrate large distances (Watters 1997). Low growth increments may be the result of muscle wastage from confined movement in tanks or low nutrition of food. Inappropriate or low energy food may have an effect on other aspects of the lithodid biology and could be a reason why post-moult females discharged uneyed eggs from their brood soon after they were extruded or did not release eggs at all after the moult.

\section{Conclusions}

The examination into the life cycle of $P$. spinosissima has given more insight into the biology of these crabs. $P$. spinosissima life history patterns appear to be similar to other species of Paralomis and very similar to its South American congener $P$. granulosa. There are however, some specific differences between the two species. $P$. spinosissima has a lower fecundity (Lovrich and Vinuesa 1999; Morley et al. 2006), larger size at sexual maturity (Otto and MacIntosh 1996) and potentially slower growth. There are still large gaps in our knowledge from a resource management perspective, especially for the early life stages. Knowledge of larval development rates at temperatures experienced in the natural environment, juvenile growth rates, time taken to sexual maturity as well as potential environmental effects on recruitment are all important in order to manage any fishery.

Acknowledgments We would like to thank the biological research teams at King Edward Point, who have kept the crab-rearing programme going for the last 5 years, and to the observers working on South Georgia's fisheries, for continually bringing us samples. This work was carried out at the British Antarctic Survey, Applied Fisheries Laboratory at King Edward Point, South Georgia, under contract to the Government of South Georgia and the South Sandwich Islands. Thanks are due to Gustavo Lovrich and two anonymous reviewers for their comments on the manuscript. 


\section{References}

Agnew DJ (2004) Fishing South. The history and management of South Georgia fisheries. Penna, St Albans

Anger K, Thatje S, Lovrich GA, Calcagno JA (2003) Larval and early juvenile development of Paralomis granulosa reared at different temperatures: tolerance of cold and food limitation in a lithodid crab from high latitudes. Mar Ecol Prog Ser 253:243-251

Anger K, Lovrich GA, Thatje S, Calcagno JA (2004) Larval and early juvenile development of Lithodes santolla (Molina, 1782) (Decapoda: Anomura: Lithodidae) reared at different temperatures in the laboratory. J Exp Mar Biol Ecol 306:217-230

Baeza JA, Fernandez M (2002) Active brood care in Cancer setosus (Crustacea: Decapoda): the relationship between female behaviour, embryo oxygen consumption and the cost of brooding. Funct Ecol 16:241-251

Calcagno JA, Lovrich GA, Thatje S, Nettelmann U, Anger K (2005) First year growth in the lithodids Lithodes santolla and Paralomis granulosa reared at different temperatures. J Sea Res 54:221-230

Collins MA, Yau C, Guilfoye F, Bagley P, Everson I, Priede IG, Agnew D (2002) Assessment of stone crab (Lithodidae) density on the South Georgia slope using baited video cameras. ICES J Mar Sci 59:370-379

Dawson EW (1989) King crabs of the world (Crustacea: Lithodidae) and their fisheries. A comprehensive bibliography. NZ Oceanol Inst Misc Publ 101:338

Frederich M, Sartoris FJ, Pörtner HO (2001) Distribution patterns of decapod crustaceans in polar areas: a result of magnesium regulation? Polar Biol 24:719-723

Hoggarth DD (1993) The life history of the lithodid crab, Paralomis granulosa, in the Falkland Islands. ICES J Mar Sci 50:405-424

Lovrich GA, Vinuesa JH (1993) Reproductive biology of the false southern king crab (Paralomis granulosa, Lithodidae) in the Beagle Channel, Argentina. Fish Bull 91:664-675

Lovrich GA (1997) La pesquería mixta de las centollas Lithodes santolla y Paralomis granulosa (Anomura: Lithodidae) en Tierra del Fuego, Argentina. Invest Mar (Valparaíso) 25:41-57

Lovrich GA, Vinuesa JH (1999) Reproductive potential of the lithodids Lithodes santolla and Paralomis granulosa (Anomura, Decapoda) in the Beagle Channel, Argentina. Sci Mar 63:355-360

Morley SA, Belchier M, Dickson J, Mulvey T (2006) Reproductive strategies of sub-Antarctic lithodid crabs vary with habitat depth. Polar Biol 29:581-584

Otto RS, Macintosh RA (1996) Observations on the biology of the lithodid crab Paralomis spinosissima from the Southern Ocean near South Georgia. In: High latitude crabs: biology, management and economics. Alaska Sea Grant College Progr Rep No 96-02. University Alaska, Fairbanks, pp 627-647

Purves MG, Agnew DJ, Moreno G, Yau C, Pilling G (2003) Distribution, demography, and discard mortality of crabs caught as bycatch in an experimental pot fishery for toothfish (Dissostichus eleginoides) in the South Atlantic. Fish Bull 101:874-888

Sloan NA (1985) Life-history characteristics of fjord-dwelling golden king crab Lithodes aequispina. Mar Ecol Prog Ser 22:219228

Somerton DA (1981) Contribution to the life history of the deep sea king crab Lithodes couesi, in the Gulf of Alaska. Fish Bull 79:259-269

Stevens BG (2006) Timing and duration of larval hatching for blue king crab Paralithodes platypus Brandt, 1850 held in the laboratory. J Crust Biol 26:495-502

Thatje S (2004) Reproductive trade-offs in benthic decapod crustaceans of high southern latitudes: tolerance of cold and food limitation. Ber Polar Meeresforsch (Rep Polar Mar Res) 483:1-183

Thatje S, Calcagno JA, Lovrich GA, Sartoris FJ, Anger K (2003) Extended hatching periods in the Subantarctic lithodid crabs Lithodes santolla and Paralomis granulosa (Crustacea: Decapoda). Helgol Mar Res 57:110-113

Thatje S, Arntz WE (2004) Antarctic reptant decapods: more than a myth? Polar Biol 27:195-201

Thatje S, Anger K, Calcagno JA, Lovrich GA, Pörtner HO, Arntz WE (2005) Challenging the cold: crabs reconquer the Antarctic. Ecology 86(3):619-625

Watters G (1997) Preliminary analyses of data collected during experimental phases of the 1994/95 and 1995/6 Antarctic crab fishing seasons. CCAMLR Sci 4:141-158

Watts J, Thatje S, Clarke S, Belchier M (2006) A description of larval and early juvenile development in Paralomis spinosissima (Decapoda: Anomura: Paguroidea: Lithodidae) from South Georgia waters (Southern Ocean). Polar Biol 29:581-584

Wenner AM, Fusaro C, Oaten A (1974) Size at onset of sexual maturity and growth rate in crustacean populations. Can $\mathrm{J}$ Zool 52:1095-1106

Zaklan SD (2002) Review of the family Lithodidae (Crustacea: Anomura: Paguroidea): Distribution, biology, and fisheries. In: Paul AJ, Dawe EG, Elner R, Jamieson GS, Kruse GH, Otto RS, SainteMarie B, Shirley TC, Woodby D (eds) Crabs in cold water regions: biology, management, and economics. University of Alaska Sea Grant College Program AK-SG-02-01, Fairbanks, AK, USA, pp 751-845 